\begin{tabular}{c} 
Politik Indonesia: Indonesian Political Science Review 2 (2) (2017) 159-178 \\
Politik Indonesia \\
Indonesian Political Science Review \\
http://journal.unnes.ac.id/nju/index.php/JPI \\
\hline Indonesia
\end{tabular}

\title{
Evaluasi Kebijakan Pendelegasian sebagian Kewenangan Bupati kepada Camat di Kecamatan Sagala Herang Subang Tahun 2015
}

\author{
Nanang Suparman ${ }^{1 凶}$ \\ ${ }^{1}$ Universitas Islam Negeri Sunan Gunung Djati, Indonesia
}

Info Artikel Abstrak

Sejarah Artikel:

Diterima 18 Mei 2017

Disetujui 7 Juli 2017

Dipublikasi 15 Juli 2017

Keywords:

Authority Delegation;

Camat; Licence Service
Upaya untuk mendorong peran Kecamatan lebih optimal dalam pelayanan masyarakat salah satunya dengan memberikan kewenangan dalam bidang perizinan sebagai salah satu bagian pelimpahan kewenangan (UU No. 23 Tahun 2014). Kabupaten Subang telah melaksanakan pelimpahan kewenangan ini sejak Tahun 2012. Pelayanan perizinan di Kecamatan selain menghemat waktu dan biaya dapat berkontribusi pada PAD, oleh sebab itu dalam penelitian ini mencoba menganalisis hasil evaluasi pelaksanaan kebijakan pelimpahan kewenangan tahun 2015 dengan kerangka pemikiran pada dua aspek yakni upaya apa saja yang telah dilakukan dan hambatan yang dihadapi. Metode deskriptif-kualitatif, selanjutnya teknik pengumpulan data melalui observasi, analisis dokumentasi dan wawancara mendalam. Hasil penelitian menunjukkan bahwa evaluasi untuk mengukur optimalisasi pelaksanaan pelimpahan kewenangan bupati di bidang perizinan kepada camat belum dapat mencapai tujuan dari perumusan kebijakan, hal tersebut dipengaruhi oleh faktor belum adanya inovasi dan kreatifitas pelayanan, belum dapat menciptakan kepastian hukum, dan belum mampu mendayagunakan kewenangan yang dilimpahkan karena Kecamatan Sagala Herang belum dapat menyiapkan perangkat administrasi yang diperlukan meliputi sumberdaya aparatur yang khusus menangani kewenangan perizinan.

\section{Abstract}

The effort to encourage more subdistrict optimal roles in comunity service by giving authority in the field of licensing as one part delegating authority (Law No.23 of 2014). Subang regency has been implementing this delegating authority since 2012. Licensing services in subdistrict in addition to saving time and costs, can contribute to the $P A D$, therefore in this study tries to analysis the result of evaluation of the implementation of policy delegating authority in 2015 with a frame of thought on two aspects i.e.what effort have been made and obstacles encountered.This research uses descriptive qualitative approach method, technique of collecting data through observation, documentation analysis and in-dept interview. The results showed that the evaluation to measure the optimalization of delegation of Bupati authority in licensings aspect to Camat can not achieve the goals of policy formulation, it is influenced by factors not yet the existence of the innovation and creativity of public service, have't yet been able to create legal certainty, and have't been able to efficiently utilize the authority assigned because sub-district Sagala Herang have't been able to set up the necessary administrative devises includes a special apparatus resources to handle the licensing authority.

(C) 2017 Universitas Negeri Semarang

$\triangle$ Alamat korespondensi: ISSN $2477-8060$ 


\section{Pendahuluan}

Bergulirnya perundang-undangan tentang Pemerintahan Daerah (UndangUndang Nomor 23 Tahun 2014), kecamatan merupakan teritorial bagian dari daerah kabupaten atau kota dimana dipimpin oleh camat dan merupakan salah satu unsur perangkat daerah kabupaten/kota. Pergeseran paradigma tata kelola penyelenggaraan pemerintahan daerah dari titik tolak perubahan definisi yang sebelumnya kecamatan sebagai komponen pemerintahan administratif kewilayahan diatasnya berurutan pemerintahan nasional, provinsi, kabupaten/ kota menjadi wilayah kerja dari perangkat daerah. Pergeseran peran telah menjadikan format berbeda kecamatan tidak lagi merepresentasikan wilayah kekuasaan namun wilayah pelayanan.

Sebagai organisasi perangkat daerah kabupaten atau kota, kecamatan berkedudukan strategis menunjang penyelenggaraan pemerintahan daerah, dikarenakan pemerintah kecamatan langsung berhadapan dengan masyarakat yang dilayaninya dan sekaligus mempertanggungjawabkan kinerja pelayannnya.

$$
\text { Sebagai organisasi publik }
$$

diharapkan lebih kompetitif serta mampu membenahi diri dalam mengemban tugas dan tanggungjawabnya. Apalagi saat ini posisi kecamatan yang dipimpin oleh camat sebagaimana tersebut diatas adalah perangkat daerah yang menjalankan kewenangan bupati atau walikota setelah mendapat pendelegasian atau alih komando. Begitu juga di Subang, camat dalam menjalankan urusan dan atau kewenangan harus sudah mendapat pendelegasian atau pelimpahan dari bupati, hal tersebut diwujudkan dengan Peraturan Bupati Subang Nomor 17 Tahun 2012 tentang Pelimpahan Sebagian Kewenangan Bupati Kepada Camat, yang mana salah satu kewenangan strategis yaitu kewenangan perizinan, sebagai pilot projek pengembangan jangka menengah pemerintah daerah dalam meningkatkan kapasitas pemerintahan di tingkat kecamatan juga mendorong perekonomian menyentuh wilayah lebih dalam dari jangkauan ibu kota kabupaten.

Perizinan di tingkat kecamatan pada lingkup Pemerintah Kabupaten Subang memegang peranan penting dalam rangka mendongkrak PAD dan percepatan pelayanan publik kepada masyarakat. Desentralisasi terjadi dalam dua aspek yaitu, desentralisasi administrasi pemerintahan dan desentralisasi administrasi keuangan. Keduanya, dimaksudkan untuk melimpahkan kewenangan kepada daerah agar dapat menggali kemampuan dan potensi daerah masing-masing sehingga dapat memberikan manfaat bagi Kecamatan Sagala Herang salah satu Kecamatan yang ada di Kabupaten Subang, harus dapat melaksanakan pengelolaan perizinan di tingkat kecamatan sesuai dengan kewenangan yang dilimpahkan oleh bupati sebagai kepala daerah.

Antusiasme masyarakat untuk mengurus perizinan telah meningkat seiring 
sosialisasi dari pemerintah baik pusat maupun daerah tentang pentingnya memiliki surat izin usaha, surat izin mendirikan bangunan. Terkait eksistensi Kecamatan Sagala Herang merupakan kawasan pariwisata agro dan bertetangga dengan Kecamatan Ciater yang telah dikenal luas sebagai salah satu destinasi pariwisata nasional dengan obyek wisata air panas Sari Ater dan dekat ke obyek wisata Tangkuban Parahu, kawasan wisata Lembang dan sekitarnya hal ini mengiindikasikan potensi perokonomian yang besar. Namun yang terpenting selama ini masyarakat Kecamatan Sagala Herang umumnya kesulitan mengurus izin usaha, IMB, dan izin lainnya yang harus diurus ke Ibu Kota Kabupaten Subang, disamping berjarak cukup jauh, pelayanan untuk seluruh masyarakat seKabupaten terpusat pada satu Kantor berlokasi di pusat kota Subang yang kemudian memunculkan fenomena antrian yang panjang, prosedur yang berbelit-belit, biaya tinggi sehingga meredupkan semangat masyarakat dalam mengurus bidang perizinan. Kecamatan dituntut mampu mengemban visi, misi pelayanan daerah. Namun yang terpenting mampu mewujudkannya, mengutip pendapat Heinrich (2007).

"The vision and mission of the government no longer relies on the setting but has shifted to services that are effective, efficient, representative, and responsive".

Tabel 1. Persebaran Penduduk Berdasarkan Desa di Kecamatan Sagala Herang.

\begin{tabular}{|c|l|c|c|c|c|}
\hline \multirow{2}{*}{ No } & \multirow{2}{*}{ Nama Desa } & \multirow{2}{*}{$\begin{array}{c}\text { Luas } \\
\text { Wil }\end{array}$} & \multicolumn{2}{|c|}{ Jenis Kelamin } & \multirow{2}{*}{\begin{tabular}{c} 
Jumlah \\
\cline { 3 - 4 }
\end{tabular}} \\
& & Laki-laki & Perempuan & Penduduk \\
\hline 1 & Sagala Herang & 5,67 & 2.625 & 2.595 & 5.220 \\
\hline 2 & Sagala & 9,37 & 2.660 & 2.738 & 5.398 \\
& Herang Kaler & & & & \\
\hline 3 & Curug Agung & 4,56 & 1.950 & 1.978 & 3.928 \\
\hline 4 & Leles & 6,63 & 1.889 & 1.999 & 3.888 \\
\hline 5 & Dayeuhkolot & 5,97 & 2.617 & 2.617 & 5.234 \\
\hline 6 & Sukamandi & 8,96 & 1.560 & 1.542 & 3.102 \\
\hline 7 & Cicadas & 9,29 & 1.746 & 1.753 & 3.499 \\
\hline & Jumlah & $\mathbf{5 0 , 4 5}$ & $\mathbf{1 5 . 0 4 7}$ & $\mathbf{1 5 . 2 2 2}$ & $\mathbf{3 0 . 2 6 9}$ \\
\hline
\end{tabular}

Sumber: Kec. Sagala Herang Tahun. 2015, diolah.

$$
\text { Berdasarkan latar belakang }
$$

pelaksanaan, terutama di bidang perizinan Sagala Herang, memegang peranan penting karena kewenangan ini konsekuensinya pada pengelolaan administrasi, pengendalian tataruang kecamatan serta benefit keuangan sebagai akibat dari pelayanan di bidang perizinan yang dapat mendekatkan pelayanan kepada masyarakat, percepatan pelayanan itu sendiri, pengendalian tata ruang kecamatan, dan kontribusi pendapatan daerah. Adapun evaluasi kebijakannya berkaitan dengan sampai sejauhmana optimalisasi dari pelaksanaan pelimpahan sebagian kewenangan tersebut dilaksanakan oleh camat selaku penerima pelimpahan atau delegasi kewenangan dari bupati tersebut adalah menjadi fokus kajian ini yang kemudian dianalisis dengan tahapan evaluasi Jones (1984: 168) meliputi: spesifikasi, pengukuran, analisis, dan rekomendasi.

Rumusan masalah yang diajukan dalam kajian ini yaitu tentang perizinan Sagala Herang Tahun 2015 dalam penyelenggaraan pemerintahan kecamatan, termasuk efektivitas dan efisiensi pelaksanaan penyelenggaraan perizinan di tingkat kecamata yang perlu secara periodik atau berkala dilakukan evaluasi, dalam rangka mencapai hasil yang 
diharapkan sebagaimana tujuan yang telah ditetapkan. Maka rumusan pertanyaan penelitian (Research Question) yang dijadikan landasan adalah 1) Apakah pelaksanaan perizinan Sagala Herang telah sesuai dengan tujuan perumusan kebijakan tersebut?; 2) Apa upaya Kecamatan Sagala Herang dalam mencapai tujuan perumusan perizinan Sagala Herang?.

Tujuan kajian ini adalah untuk mendeskripsikan hasil perizinan Tahun 2015 sejauhmana telah mampu mendorong perumusan dan implementasi bidang perizinan dijalankan searah dengan tujuan yang telah ditetapkan yakni mewujudkan pelayanan perizinan yang mudah dijangkau masyarakat mewujudkan pengendalian tata ruang kecamatan dan kontribusi pada Pendapatan Asli Daerah.

Berdasarkan referensi pelaksanaan, terutama di bidang perizinan Sagalaherang, memegang peranan penting karena kewenangan ini konsekuensinya kepada pengelolaan administrasi dan pengendalian serta keuangan sebagai akibat dari pelayanan di bidang perizinan yang dapat menghasilkan pendapatan asli daerah, disamping selain mendekatkan pelayanan kepada masyarakat, dan percepatan pelayanan itu sendiri. Adapun evaluasi kebijakannya berkaitan dengan sampai sejauhmana optimalisasi dari pelaksanaan pelimpahan sebagian kewenangan tersebut dilaksanakan oleh camat selaku penerima pelimpahan atau delegasi kewenangan dari bupati tersebut adalah menjadi fokus penulis.

\section{Tinjauan Teori}

\section{Konsep Evaluasi Kebijakan}

Menurut Bryan \& White (1987: 15)

Pengertian evaluasi mengandung makna sebagai alat penilaian, pengertian lain evaluasi ialah proses mencatat, melakukan penilaian tentang apa yang terjadi dan penyebabnya, secara elementer evaluasi adalah mengumpulkan informasi tentang keadaan sebelum dan sesudah pelaksanaan suatu program/rencana. Selanjutnya Charles O. Jones menyatakan: "evaluation is an activity which can contribute greatly to the understanding and improvement of policy development and implementation" (evaluasi adalah kegiatan yang dapat menyumbangkan pengertian yang besar nilainya dan dapat pula membantu penyempurnaan pelaksanaan kebijakan beserta perkembangannya).

Sedangkan Arifin Zainal (2010: 1) mengartikan, "evaluasi terdiri dari proses menentukan hasil yang telah dicapai dalam beberapa kegiatan yang direncanakan untuk mencapai tujuan". Selanjutnya disebutkan, bahwa evaluasi merupakan proses untuk memasok informasi tentang hasil penilaian atas permasalahan yang diungkap. Berbeda dengan pendapat lainnya, Budiman Rusli (2013: 5-6) evaluasi menitik beratkan pada proses bukan pada hasil yang didapatkan.

Sementara mengacu pada pendapat Ernest R. Alexander (2007), evaluasi 
pendekatan pada cara, diklasifikasikan menjadi lima cara sebagai berikut: 1) Before and after comparisons, cara ini menelaah tentang obyek evaluasi dengan komparasi antara kondisi sebelum dan kondisi sesudahnya; 2) Actual versus planned performance comparisons, cara dimana menelaah suatu obyek evaluasi mengkomparasi kondisi yang ada (actual) dengan penentuan perancangan ditetapkan (planned); 3) Experintal (controlled) model, dengan cara menelaah obyek evaluasi melalui serangkaian kegiatan percobaan yang terkendali untuk mengetahui kondisi yang diteliti; 4) Quasi experimental models, cara yang dipakai dalam menelaah obyek evaluasi melalui serangkaian tindakan uji coba dengan mengabaikan pengontrolan/pengendalian terhadap kondisi yang diteliti; dan 5) Cost oriented model, dengan cara menelaah sasaran penelitian hanya berlandaskan pada kriteria pengeluaran.

Evaluasi kebijakan, setidaknya memiliki dua tugas utama yaitu untuk menilai sejauhmana program mencapai tujuan atau dampak yang diinginkan ataukah tidak dan untuk menilai keberhasilan atau kegagalan dari suatu kebijakan berdasarkan standar atau kriteria yang telah ditetapkan sebelumnya. Terkait hal tersebut, ada beberapa aktivitas dalam evaluasi kebijakan. Aktivitas atau kegiatan tersebut adalah spesifikasi (spesfication), penilaian (measurement), analisis dan rekomendasi. Sebagaimana yang dikemukakan Jones (1984: 199), bahwa:
Evaluation, is an activity to judge the merits of government program or process. The subactivities identified: specification, measurement, analysis, and recommendation characterized all forms of evaluation. Penjelasan dari masing-masing dimensi adalah Specification is the most important of these subactivities. It refers to the identification of the goals or criteria by which program or process to be evaluated; Specification is trigger activity for evaluation. Measurement simply refers to the collection of information relevant to the object of evaluation. It may be very precise (example, a vehicle count to determine highway use) or imprecise and impressionistic (example, a legislator's casual visit with nursing home patients to check on improvements resulting from a new federal program).

Analysis is the absorption and use of the information collected in order to draw conclusion. Here too one finds significant differences in method and style.

Finally, recommendation is the determination of what should be done next, including such options as letting well enough alone, doing even more of the same, making major or minor adjustments, or possibly terminating the program.

Spesifikasi terkait dengan sasaran atau rincian program yang dievaluasi. Ukuran atau kriteria ini yang dipakai untuk menilai manfaat program kebijakan. Penilaian menyangkut kegiatan informasi yang 
dikumpulkan sejalan pada obyek evaluasi, sedangkan analisis adalah penggunaan informasi yang telah terkumpul dalam rangka menyusun kesimpulan. Rekomendasi yakni penentuan tentang apa yang harus dilakukan di masa datang (ex ante) Mengacu pada berbagai pendapat para ahli kebijakan publik tersebut di atas, penulis berpendapat bahwa evaluasi kebijakan publik dapat dikatakan sebagai suatu proses mengidentifikasi tujuan atau kriteria dari program kebijakan yang akan dievaluasi melalui aktivitas pengumpulan informasi yang relevan terhadap objek evaluasi, sehingga diperoleh informasi yang dapat diolah atau dapat digunakan dalam rangka menyusun kesimpulan dan menghasilkan suatu penentuan mengenai apa yang harus dilakukan di masa yang akan datang sebagai bentuk rekomendasi.

\section{Konsep Pelimpahan Kewenangan}

Hadjon Philipus M (2012: 1) terkait otoritas mengemukakan "terminologi otoritas setara dengan istilah "bevoegdheid" pada terminologi hukum Belanda. Kedua terminologi ini mengemuka distingsi yang terletak pada karakter hukumnya, yaitu istilah "bevoegdheid" digunakan baik dalam konsep hukum publik maupun dalam konsep hukum privat, sementara istilah wewenang atau kewenangan selalu digunakan dalam konsep hukum publik.

Secara konseptual yang mengkaji otoritas, (bevoegdheid) dipahami sebagai kekuasaan hukum (rechsmacht), dimana konsep tersebut diatas, berhubungan pula dalam pembentukan besluit (keputusan pemerintahan) yang harus diorientasikan pada tataran otoritas. Philipus M. Hadjon (2012: 1) S.F. Marbun (2011: 34), berpendapat otoritas mempunyai makna kemampuan dalam merealisasikan suatu tindakan hukum publik, atau secara yuridis adalah kemampuan bertindak yang diberikan oleh undang-undang yang berlaku untuk melakukan hubunganhubungan hukum. Otoritas berdampak terhadap pergaulan hukum, setelah dinyatakan dengan tegas otoritas dapat dipandang absah, baru kemudian tindak pemerintahan mendapat kekuasaan hukum (rechtskracht) konsep otoritas itu sendiri akan berkaitan dengan kekuasaan.

\section{Kewenangan Bupati Kepada Camat Dalam}

\section{Kerangka Otonomi Daerah}

Otonomi daerah terkait erat dengan konsep desentralisasi dimana otonomi daerah merupakan manifestasi desentralisasi. Bergulirnya otonomi daerah sejatinya dimaksudkan untuk memberi ruang kreasi kepada pemerintahan daerah untuk terciptanya pelayanan publik yang lebih baik dan peningkatan kesejahteraan masyarakatnya. Tetapi kemudian tentu ada batasan dalam pelaksanakannya untuk tidak melampaui wewenang pemerintah pusat yang mendelegasikan urusan-urusan kepada daerah. Sebagaimana pendapat Ryass Rasyid (2002) bahwa: 
"Otonomi daerah bukanlah merupakan hak dari masyarakat dan pemerintah daerah, melainkan kewajiban daerah dalam rangka mensukseskan pembangunan dengan sarana untuk mencapai kesejahteraan rakyat yang harus diterima dan dilaksanakan dengan penuh tanggung jawab."

Menelisik kajian otonomi daerah di Indonesia, mengemuka pandangan umum bahwa otonomi daerah sebagai alternatif yang kompatibel dengan kondisi tanah air, sebagaimana disampaikan Ryass (2002), bahwa:

"Kebijakan desentralisasi dan otonomi
daerah, mungkin merupakan satu-
satunya kebijakan yang paling besar
peluangnya untuk sukses. Ini
didasarkan pada adanya suatu
komitmen reformasi yang diterima
secara nasional didukung perangkat
hukum yang jelas dan komitmen awal
yang sangat kuat, serta diterima secara
luas oleh pemerintah daerah, partai
politik, organisasi masa, dan kaum
intelektual."

Dalam kontek mikro pemerintahan yang mencakup pendelegasian kewenangan, Wasistiono (2014: 53) mengatakan, bahwa: Dikaitkan dengan pendelegasian sebagian kewenangan pemerintahan dari bupati kepada camat, dapat dibedakan adanya 2 (dua) pola yaitu: 1) Pola Seragam, 2) Pola Beranekaragam.

Pendelegasian pola seragam yaitu mendelegasikan sebagian kewenangan pemerintahan dari bupati/walikota kepada camat secara seragam tanpa melihat karakteristik wilayah dan penduduknya relatif homogen. Adapun pendelegasian dengan pola beranekaragam yaitu mendelegasikan sebagian kewenangan dengan memperhatikan karakteristik wilayah dan penduduknya masing-masing kecamatan. Pada pola ini ada dua macam kewenangan yang sama untuk semua kecamatan, serta kewenangan kondisional, yaitu kewenangan yang sesuai dengan kondisi wilayah dan penduduknya.

\section{Metode Penelitian}

Penelitian ini menggunakan metodologi penelitian deskriptif-kualitatif, hal ini sejalan dengan karakteristik objek penelitian. Metode penelitian deskriptif-kualitatif dipilih dalam penelitian ini untuk menganalisis hasil evaluasi pelimpahan sebagian kewenangan Bupati kepada Camat dalam bidang perizinan dan fenomena pelayanan perizinan yang berlangsung di Kecamatan Sagala Herang Kabupaten Subang Jawa Barat menurut perspektif para pelaku baik para investor, masyarakat, maupun para aparat yang memberikan pelayanan.

Pendekatan penelitian kualitatif dilakukan mengingat bahwa data hanya dapat dipahami dan diungkap melalui persepsi dan interpretasi para pelaku yang sulit diukur secara kuantitatif sehingga pemaknaan yang tepat hanya dapat diberikan oleh orang yang terlibat dalam perumusan keputusan pelimpahan kewenangan bupati kepada camat bidang perizinan sebagai fokus kajian. Selain itu dengan melakukan pendekatan kualitatif, 
dapat melahirkan empati peneliti untuk dapat mengadaptasi diri dengan beragam realitas dan dinamika kehidupan masyarakat dan investor yang mengajukan perizinan dan dengan pihak aparatur yang menjalankan kewenangan.

Teknik pengumpulan data dilakukan melalui observasi, wawancara (indepth interview), dan dokumentasi. Selanjutnya analisis data, setelah data lapangan terkumpul melalui tahapan-tahapan antara lain; pertama dilakukan reduksi data (data reduction), kedua menampilkan data (data display), dan yang ketiga penyimpulan (data drawing conclusion/ verification) (Sugiyono, 2012) Penjaminan keabsahan dan kehandalan data selanjutnya dilakukan triangulasi data dengan melakukan cek, kroscek dan validasi data kepada pihak-pihak yang terkait.

Informan dalam penelitian ini ditetapkan berdasarkan teknik Purposive yaitu teknik penentuan sampel dengan pertimbangan tertentu (Sugiyono, 2010: 85) Berdasarkan hal tersebut, informan yang dipilih dalam penelitian ini terdiri dari aktoraktor perumus Keputusan Bupati tentang Pelimpahan Sebagian Kewenangan Bupati kepada Camat, yaitu diantaranya Bupati Subang, Sekretaris Daerah, Asisten Tata Praja, Irda, Kepala DPPKAD, Kepala Bagian Pemerintahan, Kepala Bagian Hukum serta Camat lokasi penelitian di Kecamatan Sagala Herang Kabupaten Subang dan 2 (dua) orang unsur masyarakat. Tokoh-tokoh tersebut di atas dipilih karena dipandang mereka mempunyai kompetensi, memiliki pengetahuan luas dan mampu menjelaskan keadaan sebenarnya tentang obyek penelitian untuk mendapatkan data yang spesifik tentang pelimpahan sebagian kewenangan bupati kepada camat di Kabupaten Subang.

\section{Pembahasan}

\section{Dimensi Pengkhususan (Spesification)}

Tujuan dari perumusan kebijakan pelimpahan sebagian kewenangan bupati di bidang perizinan kepada Camat Sagala Herang adalah untuk mendayagunakan penyelenggaraan pemerintahan daerah melalui fungsi kecamatan sebagai perangkat Daerah Kabupaten, dalam rangka menunjang pencapaian visi dan misi pembangunan daerah melalui pendelegasian kewenangan bupati kepada camat di bidang perizinan, sehingga dapat mempersingkat rentang kendali pelayanan perizinan bagi masyarakat dengan cukup dilakukan di tingkat kecamatan dan pada akhirnya akan dapat meningkatkan penerimaan Pendapatan Asli Daerah (PAD) Kabupaten Subang dari sektor perizinan. Otonomi boleh saja menjadi domain kabupaten/kota, namun frontline dari sebagian fungsi pelayanan mestinya diserahkan kepada kecamatan, disamping kepala dinas daerah/lembaga teknis daerah.

Dengan demikian, pemerintah kabupaten/kota perlu lebih mengedepankan fungsi-fungsi streering seperti koordinasi, pembinaan, fasilitasi, dan pengendalian, dari 
pada fungsi rowing atau penyelenggaraan langsung suatu urusan.

Berdasarkan uraian di atas, maka dapat dikemukakan bahwa tujuan dari perumusan kebijakan pelimpahan kewenangan Bupati kepada Camat Sagala Herang di bidang perizinan adalah untuk mendekatkan pelayanan kepada masyarakat, memperpendek rentang kendali Bupati Kepada Desa/Kelurahan yang bermuara pada penguatan institusi kecamatan, dan meningkatkan penerimaan Pendapatan Asli Daerah (PAD) Kabupaten Subang dari sektor perizinan.

Tabel 2. Sarana dan prasarana ekonomi di Kecamatan Sagala Herang yang berdampak gangguan skala kecil.

\begin{tabular}{|c|l|c|c|c|c|c|}
\hline No & \multicolumn{1}{|c|}{ Desa } & Pasar & Kios & Warung & Toko & $\begin{array}{c}\text { Hotel/ } \\
\text { Villa }\end{array}$ \\
\hline 1 & Sagalaherang & - & - & 127 & 44 & 7 \\
\hline 2 & $\begin{array}{l}\text { Sagalaherang } \\
\text { Kaler }\end{array}$ & 1 & 20 & 67 & 20 & 17 \\
\hline 3 & Curug Agung & - & - & 60 & - & 2 \\
\hline 4 & Leles & - & - & 30 & - & - \\
\hline 5 & Dayeuhkolot & - & 13 & 91 & 18 & - \\
\hline 6 & Sukamandi & - & - & 39 & 4 & - \\
\hline 7 & Cicadas & - & - & 48 & 8 & - \\
\hline & Jumlah & $\mathbf{1}$ & $\mathbf{3 3}$ & $\mathbf{4 6 2}$ & $\mathbf{9 4}$ & $\mathbf{2 6}$ \\
\hline
\end{tabular}

Sumber: Kantor Camat Sagalaherang Tahun 2015, diolah.

$$
\text { Menurut Rusli (2013: }
$$

mengemukakan tentang sasaran kebijakan publik yaitu orang-orang, kelompok orang atau organisasi-organisasi yang prilaku atau keadaannya ingin dipengaruhi atau diubah oleh kebijakan publik tersebut.

Berdasarkan hal tersebut, maka yang menjadi sasaran dari kebijakan pelimpahan sebagian kewenangan bupati di bidang perizinan kepada Camat Sagala Herang, adalah camat dan segenap aparatur kecamatan sebagai suatu organisasi perangkat daerah Kabupaten Subang yang menerima pelimpahan dari Bupati Subang untuk memberikan pelayanan perizinan di Kecamatan Sagala Herang.

Berdasarkan uraian-uraian tersebut di atas, maka dapat disimpulkan bahwa sasaran dari perumusan kebijakan pelimpahan sebagian kewenangan Bupati di bidang perizinan kepada Camat Sagala Herang adalah menciptakan pengaruh yang signifikan bagi peningkatan etos kerja dan kinerja segenap aparatur Kecamatan Sagala Herang yang lebih baik lagi dalam mendekatkan pelayanan perizinan kepada masyarakat sehingga dapat meningkatkan penerimaan pendapatan asli daerah (PAD) Kabupaten Subang dari sektor perizinan.

Menanggapi pendapat di atas, maka hasil dari pelaksanaan kebijakan pelimpahan sebagian kewenangan Bupati kepada Camat Sagala Herang di bidang perizinan, harus dapat melahirkan mekanisme pelayanan perizinan yang berkontribusi terhadap pendapatan asli daerah. Berkaitan dengan pendapat tersebut di atas, dapat disampaikan bahwa selama ini pelayanan perizinan di Kecamatan Sagala Herang belum berjalan efektif, hal ini terlihat dari belum tumbuhnya kesadaran masyarakat untuk menempuh perizinan di tingkat kecamatan, dengan alasan pelayanan yang rumit.

Pelaksanaan kebijakan Pelimpahan Sebagaian Kewenangan Bupati kepada Camat Sagala Herang di bidang perizinan, harus 
mampu menghasilkan suatu optimalisasi peran dan fungsi kecamatan dalam rangka meningkatkan pelayanan kepada masyarakat. Hasil yang diharapkan adalah terealisasikannya kecamatan sebagai pusat pelayanan masyarakat yang mudah, murah, cepat dan berkualitas.

Memperhatikan uraian-uraian di atas, maka dapat penulis simpulkan bahwa kebijakan pelimpahan sebagian kewenangan bupati di bidang perizinan kepada camat Sagala Herang, dalam pelaksanannya belum dapat mencapai tujuan dari perumusan kebijakan tersebut, yaitu untuk meningkatkan pola penyelenggaraan pemerintahan di Kecamatan Sagala Herang dalam pemberian perizinan yang dekat dengan masyarakat, dan lebih singkat dalam aspek proseduralnya, sehingga Kecamatan Sagala Herang belum dapat menunjang pencapaian target dan penggalian potensi pendapatan asli daerah (PAD) Kabupaten Subang dari sektor perizinan.

\section{Dimensi Pengukuran (Measurement)}

Proses pelaksanaan kebijakan pelimpahan kewenangan bupati di bidang perizinan kepada Camat Sagala Herang mengacu kepada Peraturan Bupati Subang Nomor 17 Tahun 2012 tentang pelimpahan sebagian kewenangan Bupati Subang kepada Camat, dalam ketentuan tersebut menyatakan bahwa kewenangan bupati yang dilimpahkan kepada camat dalam bidang perizinan mencakup perizinan dan rekomendasi Izin
Mendirikan Bangunan (IMB), Izin UndangUndang Gangguan (HO), Izin Gangguan Ringan (IGR), Surat Izin Usaha perdagangan (SIUP), Tanda Daftar Perusahaan (TDP), serta Izin Usaha Mikro dan Kecil (IUMK).

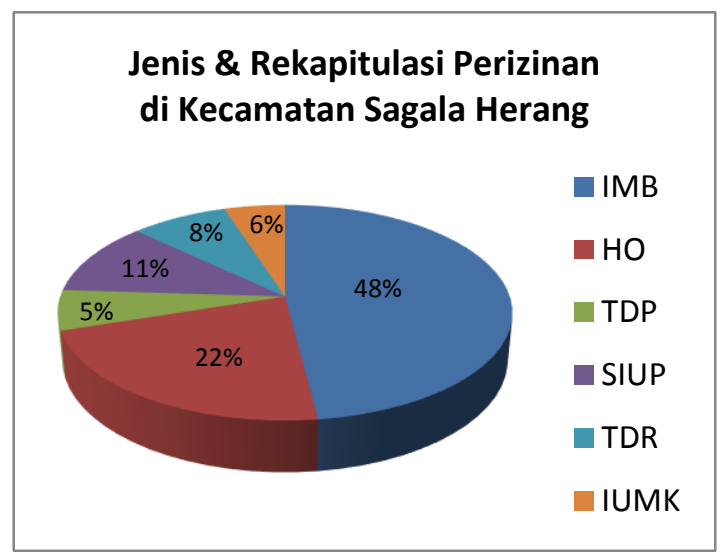

Pelaksanaan kebijakan bupati tersebut dilaksanakan oleh camat Sagala Herang dengan menerapkan mekanisme yang meliputi: a) Pembentukan Tim Pelaksana Perizinan kecamatan yang terdiri dari Penanggungjawab Tim, Ketua Tim Pelaksana, Sekretaris, Bendahara, Pengendali Operasional dan para anggota Tim yang melibatkan perangkat desa. b) Petunjuk Teknis Pelaksanaan perizinan di Kecamatan Sagala Herang dengan menerbitkan Keputusan Camat. c) menyiapkan Tempat Pelayanan Perizinan di Kantor Kecamatan.

Berkenaan dengan hal tersebut, sesuai Peraturan Pemerintah Nomor 41 Tahun 2007 tentang Organisasi Perangkat Daerah dan Peraturan Pemerintah 19 Tahun 2008 tentang Kecamatan, maka kedudukan kecamatan adalah sebagai perangkat daerah dan pelaksana tugas kewilayahan, makna utama dari posisi ini adalah sebagai pembina 
kewilayahan dan penyelenggara pelayanan masyarakat.

Berdasarkan hal tersebut, maka pelimpahan sebagian kewenangan Bupati dibidang perizinan tersebut, perlu ditelaah dan dikaji secara detail, karena tidak secara keseluruhan kewenangan bisa diberikan kepada kecamatan, tetapi didasarkan atas berbagai aspek pertimbangan. Ada empat prasyarat pelimpahan kewenangan tersebut, yaitu: pertama, adanya kemauan politik dari bupati/walikota. Kedua, kemauan politik dari pihak eksekutif dan legislatif. Ketiga, kerelaan dari dinas dan lembaga teknis daerah untuk melimpahkan kewenangan teknis yang dapat dijalankan oleh kecamatan melalui keputusan Bupati/Walikota. Kempat, dukungan anggaran dan personil dalam menjalankan kewenangan yang telah didelegasikan.

Kondisi selama ini menunjukan institusi Kecamatan Sagala Herang belum maksimal dalam melaksanakan kewenangan tersebut. Kecamatan Sagala Herang mengalami kendala, hal ini disebabkan kewenangan yang diatur masih bersifat umum (kewenangan atributif) dan sangat sedikit sesuai dengan Undang-Undang Nomor 32 Tahun 2004, pasal 126 ayat 3 , serta belum terinci dengan jelas bidang dan jenis kewenangan yang diberikan kepada kecamatan.

Pelaksanaan kebijakan pelimpahan kewenangan Bupati di bidang perizinan kepada Camat Sagala Herang dilakukan dalam rangka meningkatkan pelayanan publik di bidang perizinan kepada masyarakat secara lebih singkat dan optimal, disamping dapat mempercepat pemenuhan pelayanan itu sendiri.

Terkait pelayanan perizinan yang sudah mulai direalisasikan masih direspon negatif oleh masyarakat, keluhan yang disampaikan sebagaimana yang dimuat di portal berita online setempat Wartakini.com. yang diakses pada tanggal 14 Maret 2015 dengan judul berita: Pelayanan Perizinan di Kecamatan dinilai Setengah-Setengah. Sebagaimana disampaikan oleh Joko Agung Ketua LPKSM Kujang Nusantara.

"Seharusnya jika sudah dibentuk pelayanan di kecamatan bisa memotong birokrasi sipil. Artinya warga tak perlu lagi harus mengurus izin ke kota Subang, cukup di kecamatan. Sepertinya kedinasan di kabupaten tak rela melepas unit pelayanan yang tegolong "basah". Maksudnya dinas seperti tak mau kehilangan pendapatan atau retribusi dari pelayanan administrasi dan perizinan sipil, sekarang ini ya tetap aja masyarakat harus ke kota Subang untuk bisa tuntas pengurusannya".

Mengacu kepada pendapat di atas, dapat diketahui bahwa nomenklatur kecamatan belum dapat melaksanakan syaratsyarat implementasi pelimpahan kewenangan kepada camat sejalan dengan apa yang diuraikan di atas.

Berdasarkan hasil penelitian bahwa akuntabilitas pelaksanaan perizinan di Kecamatan Sagala Herang belum sesuai betul dengan amanat Peraturan Bupati Nomor 17 
Tahun 2012 tentang Pelimpahan Sebagian Kewenangan Bupati kepada Camat, meskipun telah diwajibkan dalam peraturan bupati tersebut.

Kecamatan Sagala Herang belum mampu mendayagunakan kewenangan yang dilimpahkan dalam menyelesaikan kebutuhan masyarakat, di sisi lain dinas-dinas tekait masih dalam pelaksanaan pelayanan ritme business as usual dan enggan melepas peran yang diembannya. Kondisi tersebut disebabkan karena Kecamatan Sagala Herang belum dapat menyiapkan perangkat yang diperlukan dalam melaksanakan pelimpahan kewenangan bupati di bidang perizinan tersebut, adapun perangkat yang diperlukan tersebut, minimal harus sudah mengantisipasi kesiapan aspek administrasi yang dimiliki untuk dapat memenuhi cakupan kewenangan yang dilimpahkan oleh Bupati kepada Camat, kesiapan administrasi tersebut, dapat dilihat dari tersedianya sumber daya aparatur yang khusus menangani kewenangan perizinan, sehingga pelaksanaan kewenangan perizinan yang diterima oleh camat tersebut dapat lebih fokus dan komprehensif dalam pelaksanaannya di Kecamatan Sagala Herang.

\section{Dimensi Analisis}

Hasil dari pelaksanaan kebijakan pelimpahan sebagian kewenangan bupati di bidang perizinan kepada kepada Camat Sagala Herang, ternyata belum dapat meningkatkan pola penyelenggaraan pemerintahan dalam pemberian perizinan yang dapat mendekatkan diri dengan masyarakat dan lebih singkat dalam aspek proseduralnya, sehingga pelaksanaan pelayanan perizinan di Kecamatan Sagala Herang tidak dapat memberikan kontribusi positif dalam rangka peningkatan PAD Kabupaten Subang dari sektor perizinan, hal ini ditunjukan dengan capaian Kecamatan Sagala Herang dalam memberikan kontribusi terhadap PAD Kabupaten Subang Tahun 2013 dan 2014 dari sektor perizinan sebagaimana dinyatakan dalam tabel 3 sebagai berikut:

Tabel 3. Prosentase Capaian Target Retribusi IMB dan HO

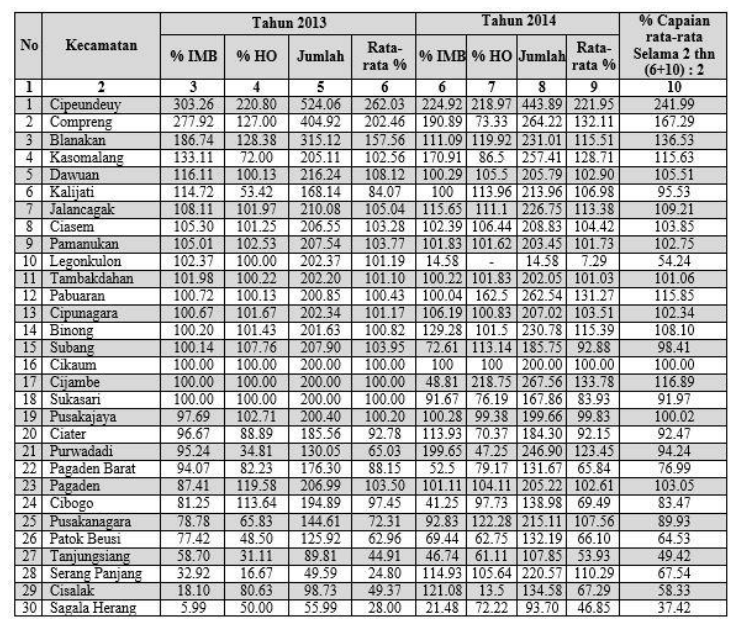

Sumber: Kantor Kecamatan Sagala Herang Tahun 2015, diolah.

Capaian kontribusi sektor perizinan sebagaimana tersebut pada tabel 1 di atas, menunjukan prosentase rata-rata capaian dari retribusi IMB dan $\mathrm{HO}$ yang dikelola oleh kecamatan sebagai tindak lanjut pelimpahan kewenangan bupati dibidang perizinan kepada Camat Sagala Herang ternyata mencapai $37.42 \%$ yang artinya berada pada urutan ke 30 atau terendah dari kecamatan-kecamatan lainnya yang ada di Kabupaten Subang. 
Berkaitan dengan pendapat tersebut, kontribusi dari perizinan IMB dan HO selama tahun 2014 dapat dilihat pada Tabel 4 sebagai berikut:

Tabel 4. Rekapitulasi Perizinan Kecamatan Sagala Herang pada tahun 2014

\begin{tabular}{|c|l|c|}
\hline No & \multicolumn{1}{|c|}{ Jenis Izin } & $\begin{array}{c}\text { Jumlah } \\
\text { Izin }\end{array}$ \\
\hline 1 & Izin Gangguan (HO) Non Industri & 25 \\
\hline 2 & Izin Mendirikan Bangunan (IMB) & 21 \\
\hline 3 & Rekomendasi & 36 \\
\hline \multicolumn{2}{|c|}{ Jumlah } & 82 \\
\hline
\end{tabular}
Sumber: Diolah peneliti.

Capaian kontribusi PAD Kabupaten Subang dari sektor perizinan di Kecamatan Sagala Herang yang tidak mencapai target dan menempati urutan terendah selama 2 (dua) tahun berturut-turut tersebut, menunjukan bahwa terdapatnya permasalahan dalam pengelolaan perizinan di Kecamatan Sagala Herang. Permasalahan tersebut tentu tidak lepas dari kapasitas camat dalam memimpin penggalian dan pengelolaan pendapatan asli daerah (PAD) di Kecamatan Sagala Herang. Diperlukan suatu pengawasan dan pembinaan yang lebih intensif terhadap seluruh komponen yang ada di Kecamatan Sagala Herang, sehingga penyebab dari rendahnya capaian kontribusi sektor perizinan terhadap PAD Kabupaten Subang dapat teratasi dan tidak terjadi lagi pada tahun yang akan datang.

Pelaksanaan pelimpahan sebagian kewenangan Bupati di bidang perizinan, ternyata belum dapat mendorong Kecamatan Sagala Herang menyelenggarakan pelayanan perizinan yang mudah, terjangkau dan transparan, hal ini disebabkan karena Kecamatan Sagala Herang masih menyelenggarakan pelayanan perizinan dengan mekanisme yang sangat sederhana dan terkesan apa adanya.

Kondisi tersebut, menyebabkan Kecamatan Sagala Herang belum dapat memberikan pelayanan secara sederhana dan cepat dalam memproses pelayanan perizinan. Khususnya bagi pelaku usaha, kondisi ini sangat mengganggu terciptanya iklim usaha yang baik, karena kepastian mekanisme, persyaratan dan waktu penyelesaian yang belum pasti sehingga tidak mendorong masyarakat dan pelaku usaha untuk mengajukan permohonan perizinan, karena belum dikemas dengan memperhatikan kebutuhan publik.

Pelimpahan kewenangan perizinan dari Bupati kepada kepada Camat Sagala Herang, tidak menghasilkan optimalisasi peran dan fungsi kecamatan dalam meningkatkan pelayanan kepada masyarakat, karena belum tegasnya pengaturan tentang teknis operasional, camat dalam melakukan koordinasi, integrasi, sinkronisasi dan simplifikasi dengan Dinas Daerah, Cabang Dinas dan UPTD sesuai dengan tugas dan fungsinya.

\section{Berdasarkan Undang-Undang Nomor} 23 Tahun 2014 tentang Pemerintahan Daerah, pasal 226 ayat (2): "Pelimpahan kewenangan Bupati/Wali Kota sebagaimana dimaksud pada ayat (1), dilakukan berdasarkan pemetaan pelayanan publik yang sesuai dengan karakteristik kecamatan dan/ atau kebutuhan masyarakat pada kecamatan yang 
bersangkutan", memperhatikan ketentuan tersebut di atas, maka perlu dikaji mengenai aspek koordinasi antar lembaga dan standarisasi tata kerja dalam pelaksanaan kebijakan pelimpahan kewenangan Bupati kepada Camat, hal ini penting karena pada umumnya, keputusan Bupati/ Walikota tentang pendelegasian kewenangan kepada Kecamatan mengatur bahwa "kewenangan yang dilimpahkan kepada Camat dilaksanakan oleh unit organisasi yang ada pada Kecamatan".

Menganalisis upaya Kecamatan Sagala Herang mencapai tujuan perumusan kebijakan pelimpahan sebagaian kewenangan Bupati di bidang perizinan, maka penulis melakukan pembahasan terhadap permasalahan-permasalahan yang timbul dari upaya yang dilakukan Kecamatan Sagala Herang dalam pelaksanaan kebijakan pelimpahan sebagian kewenangan Bupati tersebut, antara lain:

Kecamatan Sagala Herang belum dapat menciptakan kreativitas dan inovasi lokal dalam meningkatkan pelayanan kepada masyarakat, hal ini disebabkan karena kewenangan yang didistribusikan bersifat general, maka pengaruhnya terhadap format pendelegasian kewenangannya berlaku seragam untuk semua kecamatan. Tidak ada kewenangan spesifik/kondisional kepada kecamatan berdasarkan kondisi objektif/karakteristik Kecamatan. Padahal 30 Kecamatan yang berada di Kabupaten Subang mempunyai perbedaan karakter satu dan lainnya, meskipun sangat tipis perbedaannya karena letak geografis kabupaten Subang ini yang berada di pesisir pantai Utara Jawa.

Penyelenggaraan pelayanan perizinan di Kecamatan Sagala Herang belum terkelola secara terpadu, hal ini disebabkan karena masih rendahnya pemahaman para kepala desa mengenai kapasitasnya masing-masing terhadap pelimpahan kewenangan bupati kepada camat tersebut, kondisi tersebut terjadi karena kondisi sosial politik para kepala desa yang merasa dipilih dengan pemilihan langsung dan menganggap memiliki kedaulatan yang mutlak untuk mengatur urusan pemerintahan desa yang dipimpinnya, sehingga seringkali para kepala desa tersebut mengambil keputusan sendiri mengenai perizinan di wilayah desanya masing-masing.

Pelaksanaan kebijakan pelimpahan sebagian kewenangan Bupati di bidang perizinan kepada Camat Sagala Herang belum dapat dilaksanakan secara efektif, sesuai dengan Peraturan Bupati Subang Nomor 17 Tahun 2012 tentang Pelimpahan Sebagian Kewenangan Bupati kepada Camat, hal ini ditunjukan dengan belum adanya laporan mengenai pelaksanaan pelimpahan kewenangan yang disampaikan kepada Bupati melalui Sekretaris Daerah.

Pelaksanaan kebijakan pelimpahan sebagian kewenangan Bupati dibidang perizinan kepada Camat Sagala Herang, belum dapat menciptakan kepastian hukum dalam penyelenggaraan perizinan di Kecamatan Sagala Herang. Kondisi tersebut 
terjadi karena Kecamatan Sagala Herang belum dapat melaksanakan proses pengawasan dan pengendalian pelaksanaan pembangunan di tiap Desa, melalui bentukbentuk perizinan kepada masyarakat yang mengajukan izin pembangunan, sehingga kegiatan pembangunan infrastruktur dan ekonomi yang dilakukan oleh masyarakat atau publik di Kecamatan Sagala Herang belum dapat dikendalikan dan diawasi melalui sektor perizinan.

Keberhasilan penyelenggaraan urusan-urusan pemerintahan daerah termasuk misalnya urusan kepurbakalaan/kebudayaan sebenarnya tidaklah selalu berbanding lurus dengan sistem penyelenggaraan pemerintahan, apakah desentralisasi atau sentralisasi, tetapi lebih kepada komitmen, interest, dan political will dari pemerintahan setempat (Sugiharta, Sri dan Pamungkas, Tree Setiawan, 2013).

\section{Dimensi Rekomendasi}

Rekomendasi untuk meningkatkan pelaksanaan kebijakan pelimpahan kewenangan Bupati kepada Camat Sagala Herang antara lain sebagai berikut:

a. Camat Sagala Herang perlu mendorong segenap aparatur Kecamatan Sagala Herang untuk mampu memberikan pelayanan prima, dan membangun kepercayaan publik di sektor pelayanan umum, disamping harus mampu memenuhi ketersediaan sumber daya aparatur yang khusus menangani kewenangan perizinan, sehingga pelaksanaan kewenangan perizinan yang diterima oleh Camat tersebut dapat lebih fokus dan komprehensif dalam pelaksanaannya. Diperlukan suatu pengawasan dan pembinaan yang lebih intensif terhadap seluruh komponen yang ada di Kecamatan Sagala Herang dalam rangka penggalian potensi dan pengelolaan Pendapatan Asli Daerah (PAD) di Kecamatan Sagala Herang, sehingga perizinan IMB dan $\mathrm{HO}$ dapat lebih meningkat pada masa yang akan datang.

b. Kecamatan Sagala Herang perlu menciptakan penyelenggaraannya pelayanan perizinan yang memiliki standar operasional prosedur yang memenuhi persyaratan mutu, mulai dari penerimaan berkas permohonan perizinan, pengendalian proses perizinan sampai dengan menerbitkan Surat Keputusan (SK) perizinan sesuai dengan ketentuan yang ada.

Pelimpahan sebagian kewenangan di bidang perizinan bupati kepada camat selain bersifat administratif juga berimplikasi pada aspek politik, keteguhan kemauan politik kepala daerah sesuai komitmen awal dalam perumusan kebijakan senantiasa diperkuat oleh tindakan konkret memperkuat pelaksanaan kebijakan dengan ketegasan menghentikan dualisme pelayanan perizinan yang masih berjalan pada dinas dan lembaga daerah untuk selanjutnya dilaksanakan di kecamatan. 
Respon masyarakat Sagala Herang terhadap pelimpahan kewenangan bupati kepada camat dengan ditetapkannya kecamatan sebagai pusat pelayanan perizinan pada umumnya sangat antusias. Pada setiap kesempatan audensi dengan bupati pada berbagai pertemuan selalu disampaikan perihal harapan mereka akan hadirnya pelayanan (service delivery) yang lebih baik. Terkait pelayanan perizinan keinginan masyarakat agar proses perizinan dapat tuntas di kecamatan tidak sebagiannya dituntaskan di dinas/lembaga yang berlokasi di kota Subang.

Relasi masyarakat dalam menyikapi pelayanan perizinan di kecamatan diukur pada keberhasilan kualitas pelayanan perizinan yang diterimanya. Dalam mana pelayanan terus-menerus buruk, maka kanalisasi ekspresi mereka ditumpahkan melalui media masa lokal baik itu radio, televisi, media cetak maupun online. Sejauh ini kekecewaan masyarakat Kecamatan Sagala Herang seputar pelayanan yang masih harus dituntaskan di dinas/lembaga di kota Subang selain lokasi yang jauh juga birokrasi yang semakin panjang, biaya tinggi, dan menguras energi.

Kondisi tak ideal pada penerapan kebijakan pelayanan perizinan tak terlepas dari unsur tarik menarik kepentingan antara bupati dan camat dan pihak ketiga yang berkepentingan yakni para pejabat kepala dinas/lembaga yang mempunyai kedekatan kepada bupati dengan tebaran pengaruh masing-masing. Bidang perzinan dimaklumi sebagai bidang yang "basah" banyak kepala dinas/lembaga yang tidak rela diserahkan ke kecanmatan sepenuhnya.

Rekomendasi terkait aspek politis pelimpahan kewenangan bupati kepada camat bahwa penting kepala daerah bersikap firm dalam mengawal kebijakan dan meyakinkan masyarakat melalui legal opinion berupa terbitnya peraturan bupati untuk memperkuat kebijakan, memberdayakan peran camat dan menunjuk pejabat Sekretaris Daerah sebagai desk penanganan pengaduan, monitoring dan evaluasi dan tindak lanjutnya serta menyertakan anggota DPRD sebagai evaluator eksternal.

\section{Faktor-Faktor Kendala}

Berdasarkan evaluasi internal prakteknya belum berjalan dengan baik oleh beberapa faktor antara lain: 1) Kecamatan Sagala Herang belum mampu mendayagunakan kewenangan yang dilimpahkan dalam menyelesaikan kebutuhan masyarakat, kondisi tersebut disebabkan karena Kecamatan Sagala Herang belum dapat menyiapkan perangkat administrasi yang diperlukan dalam melaksanakan pelimpahan kewenangan Bupati di bidang perizinan tersebut, yang meliputi ketersediaan sumber daya aparatur yang khusus menangani kewenangan perizinan, sehingga pelaksanaan kewenangan perizinan yang diterima oleh Camat tersebut dapat lebih fokus dan 
komprehensif dalam pelaksanaannya; 2) Hasil dari pelaksanaan kebijakan pelimpahan sebagian kewenangan Bupati di bidang perizinan kepada Camat Sagala Herang, ternyata belum dapat memberikan kontribusi positif dalam rangka peningkatan PAD Kabupaten Subang dari sektor perizinan, disebabkan karena rendahnya capaian kontribusi dari perizinan IMB dan HO bila dibandingkan dengan capaian kontribusi perizinan dari Kecamatan lainnya; 3) Pelaksanaan pelimpahan sebagian kewenangan Bupati di bidang perizinan, ternyata belum dapat mendorong Kecamatan Sagala Herang menyelenggarakan pelayanan perizinan yang mudah, terjangkau dan transparan, hal ini disebabkan karena Kecamatan Sagala Herang masih menyelenggarakan pelayanan perizinan dengan mekanisme yang sangat sederhana dan terkesan melayani perizinan dengan apa adanya. Untuk mewujudkan kesesuaian terhadap tujuan perumusan kebijakan pelimpahan sebagian kewenangan bupati di bidang perizinan kepada Camat Sagala Herang, direkomendasikan hal-hal antara lain:

1) Camat Sagala Herang harus mampu mendorong segenap aparatur Kecamatan Sagala Herang untuk mampu memberikan pelayanan prima kepada masyarakat dan membangun kepercayaan publik di sektor pelayanan umum, serta memenuhi ketersediaan sumber daya aparatur yang khusus menangani kewenangan perizinan; 2) Diperlukan suatu pengawasan dan pembinaan yang lebih intensif terhadap seluruh komponen yang ada di Kecamatan Sagala Herang dalam rangka penggalian potensi dan pengelolaan Pendapatan Asli Daerah (PAD) di Kecamatan Sagala Herang.

\section{Temuan Penelitian dan Analisis Konsep}

Mencermati berbagai fenomena empirik berdasarkan hasil pengamatan maupun wawancara mendalam tentang evaluasi pelimpahan sebagian kewenangan bupati kepada camat tahun 2015 dalam bidang perizinan dapat diperoleh pemahaman bahwa spektrum ukuran penyelenggaraan pelayanan perizinan (di tingkat kecamatan) sebenarnya bagian integral dari implementasi kebijakan desentralisasi, camat sebagai sub-ordinan kepala daerah berkewajiban untuk berperan sukses meningkatkan cacity building institusi kecamatan, memperkuat basis kewilayahan dengan mendorong pertumbuhan ekonomi. Evaluasi dalam pelimpahan sebagian kewenangan Bupati kepada Camat tahun 2015 adalah mengukur, menafsirkan, dan menilai pencapaian program. Dalam evaluasi ini dilihat tentang tujuan yang telah tercapai, hasil dari program kebijakan, kebutuhan yang telah terpenuhi, dan hasil jangka menengah panjang akibat dari program pelimpahan sebagian kewenangan bupati kepada camat di bidang perizinan dengan lokus Kecamatan Sagala Herang Kabupaten Subang.

Secara koseptual, pelayanan perizinan pada dasarnya memiliki sedikitnya tiga fungsi utama: 
1. Instrumen budgeter (melalui pemungutan pajak dan retribusi daerah).

2. Instrumen pembangunan untuk membuka lapangan kerja dan meningkatkan pendapatan masyarakat.

3. Instrumen pembinaan untuk menata keserasian pembangunan sektoral dan kewilayahan.

$$
\text { Dalam konteks inilah }
$$

penyelenggaraan layanan perizinan di

kecamatan menjadi salah satu faktor pengungkit utama dalam menggerakkan roda perekonomian daerah kecamatan. Konsep pelayanan publik telah bergeser jauh dari yang semula paradigma pemerintah sebagai entitas monopolistik menjadi masyarakat yang berpartisipasi aktif, kesenadaan tersebut ditegaskan oleh Rhodes (2003: 45), saat ini tidak ada lagi kekuasaan yang dominan dalam struktur tata pemerintahan (governance). Untuk itu peran terpenting saat ini yang perlu dilakukan pemerintah pada semua strata adalah menjadi mediator dan pembangun konsensus (consencus builder). Sejalan konsep tersebut perumusan regulasi perizinan yang partisipatif menjadi sebuah keniscayaan.

\section{Penutup}

Berdasarkan temuan-temuan dalam penelitian ini dapat disimpulkan bahwa Kecamatan Sagala Herang secara legal formal melaksanakan kewenangan di bidang perizinan yang dilimpahkan. Camat sebagai Key Person dalam kebijakan ini bertindak sebagai representasi kepala daerah dan sekaligus sebagai leading administrator. Namun demikian, pada tataran operasional masih belum mampu memberikan pelayanan perizinan yang tuntas dan sesuai keinginan masyarakat, hal tersebut disebabkan masih adanya faktor-faktor kendala belum adanya inovasi dan kreatifitas pelayanan, belum dapat menciptakan kepastian hukum, dan belum mampu mendayagunakan kewenangan yang dilimpahkan.

\section{Daftar Pustaka}

Arifin, Z. (2010). Evaluasi Pembelajaran Prinsip Teknik Prosedur (Latifah Ed). Bandung: Remaja Rosdakarya.

Bappenas. (2007). Mekanisme Pelaksanaan Evaluasi Kinerja dengan Penyusunan Indikator Dan Sasaran. Jakarta: Bappenas.

Bird, R. M., \& Vaillancourt, F. (Eds.). (2008). Fiscal decentralization in developing countries. Cambridge University Press.

Bryant, C., \& White, L. G. (1982). Managing development in the Third World.

Briyant, C., Hagul, P., Simatupang, R. L., \& White, L. G. (1987). Manajemen pembangunan: untuk negara berkembang. LP3ES.

Dwiyanto, A. (2015). Administrasi publik: desentralisasi, kelembagaan, dan aparatur sipil negara. Gadjah Mada University Press bekerja sama dengan LAN RI. 
Dunn, William N. (1990). Analisa Kebijakan Publik, Terjemahan Darwin Muhadjir. Kerangka Analisa Dan Prosedur Perumusan Masalah. Yogyakarta: PT. Nanindita,

Dunn, W. N. (2015). Public policy analysis. Routledge.

Dunn, W. N. (2000). Pengantar analisis kebijakan publik. Gadjah Mada University Press.

Jones, C. O. (1970). Introduction to the study of public policy.

Keputusan Menteri Pendayagunaan Aparatur Negara Nomor 63/KEP/M. PAN/7/2003 tentang pedoman Umum Penyelenggaraan Pelayanan Publik.

Keputusan Bupati Subang Nomor 6/2002 tentang Pelimpahan Sebagian Kewenangan Bupati Subang kepada Camat. Subang.

Nugroho, R. (2003). Kebijakan Publik: Formulasi, Implementasi dan Evaluasi. Jakarta: Elex Media Komputindo.

Nugroho, R. (2008). Public policy. Jakarta: Elex Media Komputindo.

Osborne, D., \& Gaebler, T. (1996). Mewirausahakan birokrasi. Rosyid A, penerjemah. Jakarta: Pustaka Binaman Pressindo. Terjemahan dari: Reinventing Government: How the Entrepreneurial Spirit is Transforming the Public Sector.
Peraturan Bupati Subang Nomor 17 Tahun 2012 tentang Pelimpahan Sebagian Kewenangan Bupati Subang kepada Camat. Subang.Poltak, L. Reformasi Pelayanan Publik Teori, Kebijakan, dan implementasi. Bumi Aksara.

Rasyid, R. (2002). Desentralisasi dan Otonomi Daerah, Jakarata: LIPI Press.

Rhodes, R. A. (1994). The hollowing out of the state: The changing nature of the public service in Britain. The Political Quarterly, 65(2), 138-151.

Rosidin, U. (2010). Otonomi daerah dan Desentralisasi. Bandung: Pustaka Setia.

Rusli, H. B. (2013). Kebijakan Publik Membangun Pelayanan Publik Yang Responsif. Abstrak.

Siedentopf, H. (1987). Decentralization for Roral Development: Government Approaches and People's Initiative in Asia the Pacific. Building from below local initiatives for decentralized development in Asia and Pacific, 1.

Sugiyono, M. P. P. (2007). Pendekatan Kuantitatif. Kualitatif, dan R\&D, Bandung: Alfabeta.

Undang-Undang Nomor 32 Tahun 2004 tentang Pemerintahan Daerah.

Undang-Undang Nomor 23 Tahun 2014 tentang Pemerintahan Daerah.

Wasistiono, S. (2014). Opimalisasi Peran dan Fungsi Kecamatan dalam Rangka 
Nanang Suparman/ Evaluasi Kebijakan Pendelegasian sebagian Kewenangan Bupati kepada...

Optimalisasi Pelayanan Publik di

Era Otonomi Daerah. Badan Diklat

Depdagri. 